\title{
核沸騰過程におけるミクロ液膜構造に基づく伝熱特性の検討*
}

$$
\text { 中 村 考 作*1, 宇 高 義 郎*2 }
$$

\section{Heat Transfer Characteristics Based on Micro-Layer Configuration in Nucleate Boiling}

\author{
Kosaku NAKAMURA and Yoshio UTAKA*3 \\ ${ }^{* 3}$ Division of Systems Research, Yokohama National University, \\ 79-5 Tokiwadai, Hodogaya-ku, Yokohama-shi, Kanagawa, 240-8501 Japan
}

\begin{abstract}
The objective of the study is to elucidate the contribution of micro-layer on heat transfer in nucleate pool boiling of isolated bubble region on the basis of the measurement of configuration of micro-layer. The distribution of micro-layer thickness formed under a growing bubble was measured by laser extinction method using specially devised system with a thin optical fiber in thin tube and gas blowing in the previous report. In this report, the dominant factors determining the characteristics of micro-layer such as micro-layer thickness distribution, duration of micro-layer existence, size of micro-layer area on the heat transfer surface and so-forth were expressed by nondimensional form based on the similarity of bubble growth rate. Finally, the contribution of evaporation from micro-layer in nucleate boiling of isolated bubble region was shown by using the relations among dominant factors.
\end{abstract}

Key Words: Phase Change, Pool Boiling, Micro-Layer, Laser Extinction Method, Bubble, Heat Transfer

\section{1. はじめに}

核沸騰現象は, 他の熱伝達現象と比較して高い熱伝 達率を持ち, 気液両相を利用できることなどの特徵を もつため, 工業的に多く利用されている. しかし核沸 騰現象は多くの研究がなされているにも拘わらず, 気 泡の成長や運動、気液界面での相変化現象など多くの 物理化学的な要因に影響を受けるため, その伝熱機構 や特性は未だ定量的に解明されていない事項が多く残 されている.

核沸騰現象の主要な伝熱機構として,これまで気泡 擋乱機構, 顥熱輸送機構, 薄夜膜蒸発機構などが提案 されており，それらは気泡の挙動・上昇による過熱液 層内の対流促進による効果と, ミク口液膜の蒸発によ る効果に大別されるが，どちらがどのように影響をも つか定量的に明らかにされていない. 薄液膜蒸発機構 は潜熱鍮送機構とも呼ばれ，伝熱面表面と沸騰気泡と の間に形成されるミクロ液膜が蒸発することによって 大量の熱が輸送されると考えられている.

ミクロ液膜厚さに関しては, 従来から Cooper \& Lloid $^{(1)}$ の理論式が多くの研究において用いられてきて いるが，その適否についての検討は十分でなかった.

\footnotetext{
* 原稿受付 2008 年 6 月 12 日.

*1 正員, 日立アプライアンス(株) (惢329-4493 栃木県下都賀 郡大平町富田 800 ).

*2 正員, 横浜国立大学大学院工学研究院(拜 240-8501 横浜市 保土々谷区常盤台 79-5)

E-mail: utaka@ynu.ac.jp
}

前報(2)では, 図 1 に示したように, コア径 $94 \mu \mathrm{m}$ の極 細光ファイバを金属細管に通したレーザー光射出装置 を沸騰気泡上部のバルク液中に設置した．細管先端か らレーザーに対して透明な窒素気泡を放出，これを沸 騰気泡と衝突させ, 光ファイバからミクロ液膜までの 間の液体を除くための構造を考案した．沸騰系とレー ザー透過割合測定系から構成される実験装置を用いて, プール核沸騰気泡下部に存在するミク口液膜の厚さを, レーザー消光法を用いて測定した. ここで，レーザー 光がディテクタまで安定して透過可能なように, 伝熱 面には厚さ $2 \mathrm{~mm}$ の石英ガラス板を, 加熱には窒素カ ス噴流を用いた. また，発泡位置を安定させるように 伀熱面には微細なキャビティを設けた．その結果，初

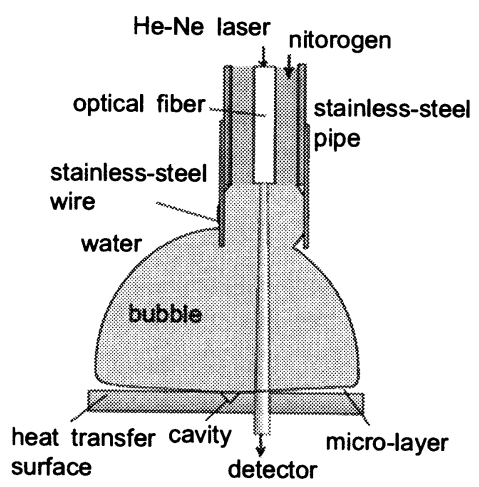

Fig.1 Measuring method of micro-layer thickness 
期ミク口液膜は $1 \sim 8 \mu \mathrm{m}$ の厚さを有し, 発泡点から離 れるにしたがって厚くなる傾向を示した.

本研究では核沸騰過程において, 前報 ${ }^{(2)}$ で示したミ ク口液膜厚さ構造と核沸騰気泡の生成および成長の過 程を同時に撮影した画像からミクロ液膜の特性を導き 出し，それらを基にミクロ液膜からの蒸発の核沸騰熱 伝達特性への影響について検討することを目的とする.

\section{纪 号}

\begin{tabular}{|c|c|}
\hline 1 & : 消光俰数 $\left[\mathrm{m}^{-1}\right]$ \\
\hline & : 伝熱面からの光ファイバ先端高さ $[\mathrm{m}]$ \\
\hline$H_{\mathrm{Bd}}$ & : 離脱時における沸騰気泡高さ [m] \\
\hline I & : レーザー光のミク口液膜透渦強度 [-] \\
\hline$I_{0}$ & : レーザー光の基準強度 [-] \\
\hline$k$ & : 熱伝導率 $[\mathrm{W} /(\mathrm{m} \cdot \mathrm{K})]$ \\
\hline$L$ & : 蒸発潜熱 $[\mathrm{J} / \mathrm{kg}]$ \\
\hline$q$ & : 熱流束 $\left[\mathrm{W} / \mathrm{m}^{2}\right]$ \\
\hline$Q_{\mathrm{ML}}$ & : ミク口液膜を通して気泡へ伝わる熱量 [] \\
\hline  & : 発泡点からの距離 [m] \\
\hline$r_{L}$ & : 発泡点と測定点間の距離 [m] \\
\hline$R_{\mathrm{M}}$ & : ミクロ液膜半径 [m] \\
\hline$R_{\mathrm{M} \max }$ & : 最大ミクロ液膜半径 $[\mathrm{m}]$ \\
\hline$R_{\mathrm{Bmax}}$ & : 最大沸騰気泡半径 [m] \\
\hline$R_{\mathrm{Bd}}$ & : 離脱時における沸騰気泡半径 [m] \\
\hline 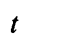 & : 沸騰気泡発生からの経過时間 [s] \\
\hline$t_{\text {Mmax }}$ & : 最大ミク口液膜半径に達する時間 [s] \\
\hline$t_{\text {Md }}$ & : 気泡発生から気泡離脱開始までの時間 $[\mathrm{s}]$ \\
\hline$t_{\mathrm{Bd}}$ & : 気泡発生から気沱離侻完了までの時間 $[\mathrm{s}]$ \\
\hline$V_{\mathrm{b}}$ & : 蒸気泡体積 $\left[\mathrm{m}^{3}\right]$ \\
\hline$V_{s}$ & : ミク口液膜からの蒸気生成体積 $\left[\mathrm{m}^{3}\right]$ \\
\hline$V_{\text {Mmax }}$ & $: R_{\mathrm{Mmax}}$ までの平均ミクロ液膜先端速度 $[\mathrm{m} / \mathrm{s}]$ \\
\hline$\delta$ & : ミクロ液膜厚さ [m] \\
\hline$\delta_{0}$ & : 初期ミクロ液膜厚さ $[\mathrm{m}]$ \\
\hline$\delta_{\max }$ & $: R_{\mathrm{Mmax}}$ における初期ミク口液膜厚さ $[\mathrm{m}]$ \\
\hline$\Delta t_{\mathrm{Me}}$ & : ミクロ液膜期間 [s] \\
\hline$\Delta T$ & : 伝熱面過熱度 $[\mathrm{K}]$ \\
\hline$\rho_{v}$ & : 蒸気密度 $\left[\mathrm{kg} / \mathrm{m}^{3}\right]$ \\
\hline & :液体密度 $\left[\mathrm{kg} / \mathrm{m}^{3}\right]$ \\
\hline
\end{tabular}

\section{2. 前報の结果}

図 2 は前報 ${ }^{(2)}$ の主要な結果である, 発泡点からの位 置に対する初期ミクロ液膜厚さ $\delta_{0}$ の変化を示してい る. 測定の範囲では $\delta_{0}$ の熱流束への依存性はみられず, 発泡点からの距離が増加するにしたがって直線的に增 加する傾向を示し, 数ミクロン前後の厚さの分布をも っていることが明らかになった. 発泡位置からの距離

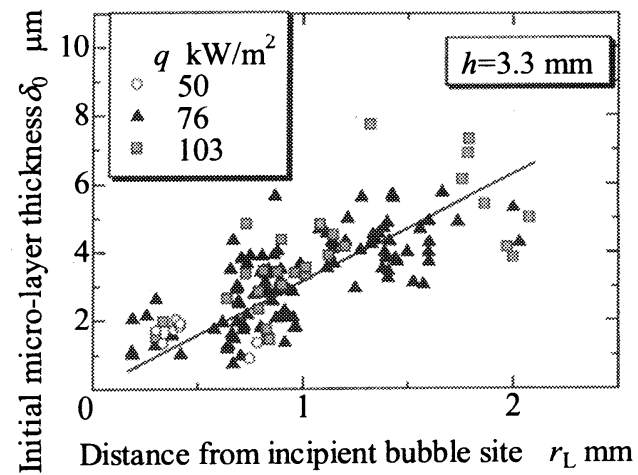

Fig.2 Variation of initial micro-layer thickness against distance from incipient bubble site

$$
\delta_{0}=3.15 \times 10^{-3} \times r_{\mathrm{L}}
$$

とミクロ液膜厚さの関係は式(1)のように表された. ま た, Cooper \& Lloidが導いたミクロ液膜厚さの理論式 と比較を行った結果, 前報で測定したミクロ液膜厚さ は Cooper \& Lloid の理論式より大幅に小さい值を示し, 気泡成長速度に対する傾向も異なる結果が得られた.

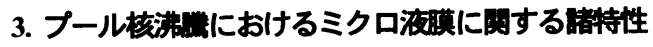

はじめに主要な支配要因に関する定義を行うため, 図 3 に沸騰父泡力溌生してからの沸騰気泡の成長形態亡経過時 間を模式的に示した. 気泡溌泡点から生成し, 成長とと もに伝熱面之の間にミク口液膜力汧成されその伝熱面上 を半径が増大してゆく. その後, 浮力等の影響により気泡 は伝熱面より離脱する. 離酚過程において, 形成されたミ クロ液膜半径は减少し, 伝熱面はバルク液て覆われミクロ 液膜は消减する. 気泡成長速度等の条件は異なっても, 図3 に示されるような気泡力溌泡してから離脱するまでのミク 口液膜半径 $R_{\mathrm{M}}$ の経时変化の傾向は類以していた ここで, 最大ミク口液膜半径 $R_{\text {Mmax }}$ が現れるまでの時間を $t_{\text {Mmax }}$, 気 泡の離侻開始時の水平方向の気泡半径を $R_{\mathrm{Bmax}}$, その時間

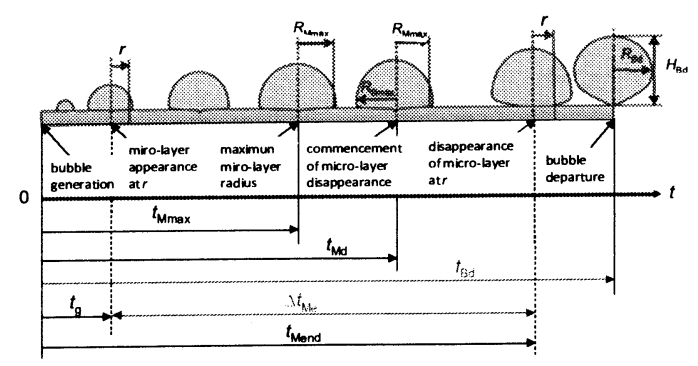

Fig.3 Definition of times relating to size of micro-layer and bubble growth 
を $t_{\mathrm{Md}}$ とする. また, 気泡離脱完了時の水平方向気泡 半径を $R_{\mathrm{Bd}}$, 気泡高さを $H_{\mathrm{Bd}}$, 時間を $t_{\mathrm{Bd}}$ とし, さらに 半径 $r$ におるミクロ液膜の存在時間をミクロ液膜期 間 $\Delta t_{\mathrm{Mc}}$ と定義する. ここで各半径およひ時間について は, 液膜厚さ測定と同期して撮影した高速度撮影画像 から值を読み取った。

図 4 に伝熱面上に搪大するミク口液膜領域の寸法を 表すミク口液膜半径 $R_{\mathrm{M}}$ の経時変化を, 測定デー夕の うちの多くの例についてまとめて示した. ミクロ液膜 半径 $R_{\mathrm{M}}$ が大きいほど存在時間は長くなるが, 熱流束 への依存性はみられないことが分かる. その寸法は概 ね 10 30 ms 程度の時間で急激に拡大し, その直後に 最大值を迎える. その後少し遅れて気泡が離脱に向か うとともに隇少し始め, 気泡の離脱とともに消滅する. 最大值を経てからは, 成長過程に比較してミク口液膜 半径は比較的ゆるやかに減少することが分かる.

図 5 は最大ミク口液膜半径 $R_{\text {Mmax }}$ に対する気泡離饼封間 $t_{\mathrm{Bd}}$ の変化を示している. 熱流束に関倸なく, $R_{\mathrm{Mmax}}$ が増

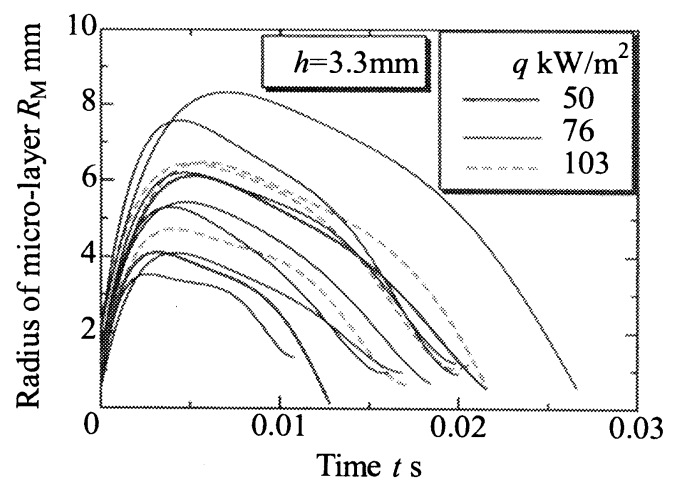

Fig.4 Variation of radius of micro-layer on heat transfer surface

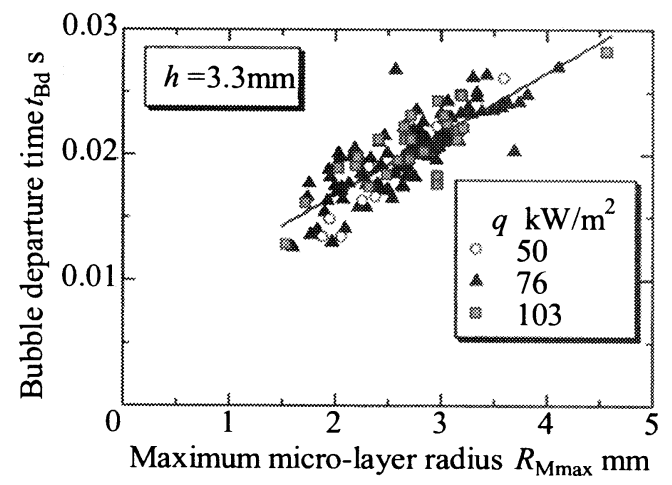

Fig.5 Variation of bubble departure time against maximum micro-layer radius
加するにしたがって $t_{\mathrm{Bd}}$ も増咐ることが分かる. 最大ミク 口液膜半径と気沒離䂱時間 の関倸は式(2)で表される.

$$
t_{\mathrm{Bd}}=4.94 \times R_{\mathrm{M} \max }+6.92 \times 10^{-3}
$$

図 6 および図 7 は，それぞれ最大ミクロ液膜半径 $R_{\mathrm{Mmax}}$ と気泡離脱半径 $R_{\mathrm{Bd}}$ の関係, および気泡離脱半 径 $R_{\mathrm{Bd}}$ と気泡離脱高さ $H_{\mathrm{Bd}}$ の関係を示している. 雨グ ラフとも直線的変化を示しており, $R_{\mathrm{Mmax}}$ と $R_{\mathrm{Bd}}$, お よび $R_{\mathrm{Mmax}}$ と $H_{\mathrm{Bd}}$ はそれぞれほぼ比例関係と見なすこ とがでる. 以上から， $R_{\mathrm{M} \text { max }}$ のときの気泡寸法は式(3) および式(4)にて表される.

$$
\begin{aligned}
& R_{\mathrm{Bd}}=1.33 \times R_{\mathrm{M} \max } \\
& H_{\mathrm{Bd}}=1.782 \times R_{\mathrm{M} \max }+9.53 \times 10^{-4}
\end{aligned}
$$

また, 最大ミクロ液膜半径 $R_{\mathrm{M} \text { max }}$ に対する $R_{\mathrm{M} \text { max }}$ の ときの初期ミクロ液膜厚さの值 $\delta_{\text {max }}$ との関係には, それらを式(1)にあてはめることにより, 式 (5) のよう に表される.

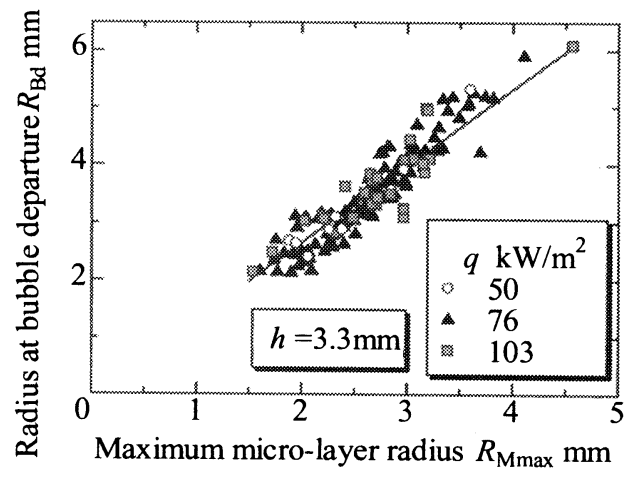

Fig.6 Variation of radius at bubble departure against maximum micro-layer radius

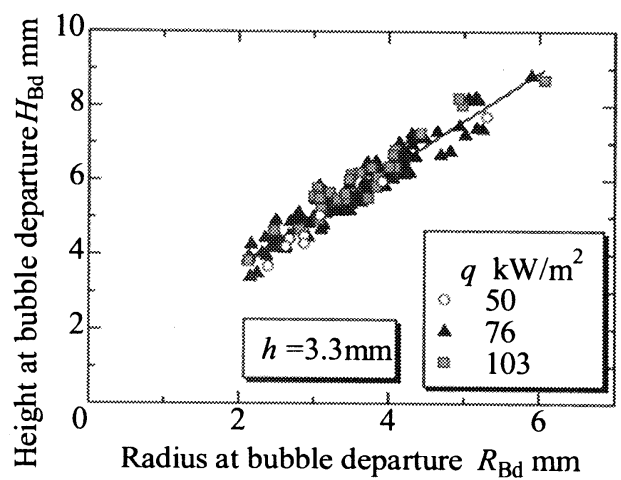

Fig.7 Variation of height at bubble departure against radius at bubble departure 


$$
\delta_{\max }=3.15 \times 10^{-3} \times R_{\mathrm{Mmax}}
$$

図 8 に位置 $r_{\mathrm{L}}$ に対するミク口液膜期間 $\Delta t_{\mathrm{Mc}}$ の変化を 示す. ミクロ液膜期間 $\Delta t_{\mathrm{Me}}$ は位置 $r_{\mathrm{L}}$ が増吅するにしたが つて減少する傾向を示した. しかし，同じ位置においても ミクロ液膜期間の值は大きく異なり, 図5 7のような良好 な関係を現していないことが分かる.

\section{4. プール核沸巍におけるミクロ液膜特性の整理}

前揭の図 4 に示したように, 気泡発泡から離脱までのミ ク口液膜半径 $R_{\mathrm{M}}$ の経時変化は気泡の離脱半径には依らず, 定性的な傾的類似していることが分かつたしたがって, 気泡成長に係わる物理要因は，ミク口液膜半径と気泡成長 時間を規格化することにより系統的な傾向を得られる可能 性が考えられる.

そのような視点から、ます図 4 で示した気泡発生から離 脱までのミク口液膜半径 $R_{\mathrm{M}}$ の経時変化を, 最大ミク口液 膜半径 $R_{\mathrm{M} \text { max }}$ と気泡離脱時間 $t_{\mathrm{Bd}}$ によって無次元化した 結果を図 9 に示した. なお, 図中の線の重なりにより条件 との対応动别かににいが，等しい条件の図 4 により区別 される. 無次元北することにより, 成長曲線はほぼ 致し,

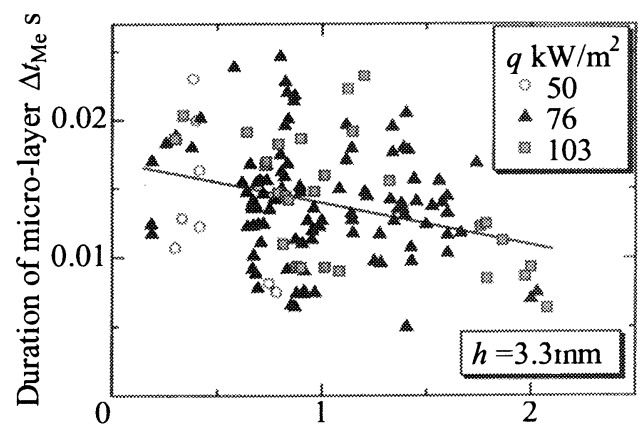

Distance from incipient bubble site $r_{\mathrm{L}} \mathrm{mm}$

Fig.8 Variation of duration of micro-layer against position

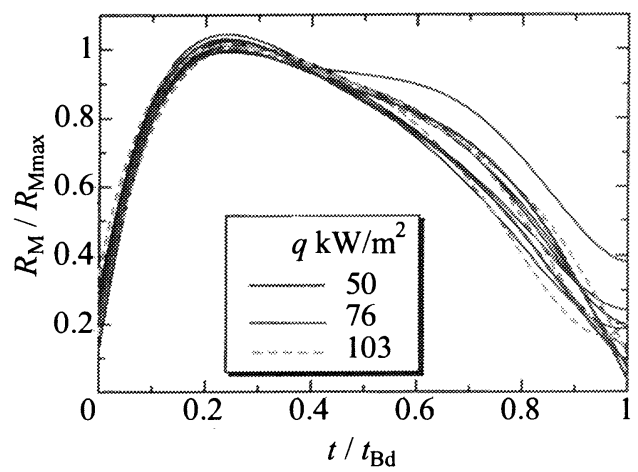

Fig.9 Variability of dimensionless radius of micro-layer over dimensionless time
ミクロ液膜は相似的に成長することか確認される. したが つて，上述のように，ミクロ液膜成長に関する諸要因につ いてはこのような無次元化を利用することによってより 良好な整理につながると考えられる.

図 8 で示した局所位置とミクロ液膜期間の関係を, それぞれ最大ミクロ液膜半径 $R_{\mathrm{M} \text { max }}$ と気泡離脱時間 $t_{\mathrm{Bd}}$ により無次元化して表した結果を図 10 に示した. このような無次元化により, 図 8 の結果と比べてまと まりの向上が確認される. 無次元位置と無次元存在時 間の関係は式(6)で表される.

$$
\frac{\Delta t_{\mathrm{Me}}}{t_{\mathrm{Bd}}}=-0.674 \times \frac{r_{\mathrm{L}}}{R_{\mathrm{M} \max }}+0.946
$$

図 2 で示した, 初期ミクロ液膜厚さ $\delta_{0}$ と位置 $r_{\mathrm{L}}$ の関 係についても同様の整理を行つた. 図 11 の座標は, $R_{\mathrm{Mmax}}$ における初期ミクロ液膜厚さ $\delta_{0}$ の最大值 $\delta_{\text {max }}$ および $r_{\mathrm{L}}$ を $R_{\mathrm{M} \max }$ により規格化したものである.

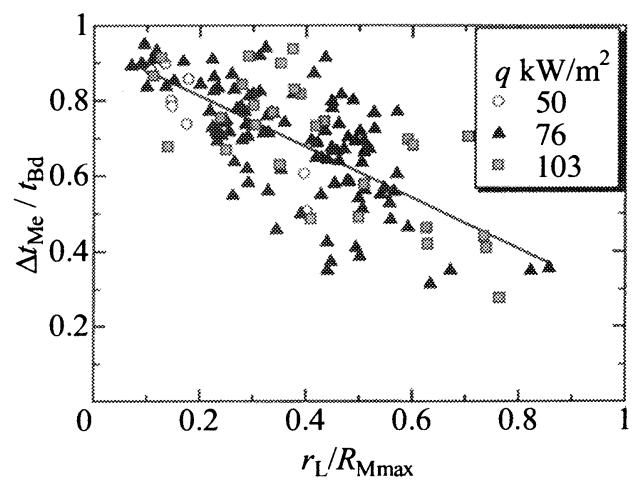

Fig.10 Variation of dimensionless duration of micro-layer against dimensionless position

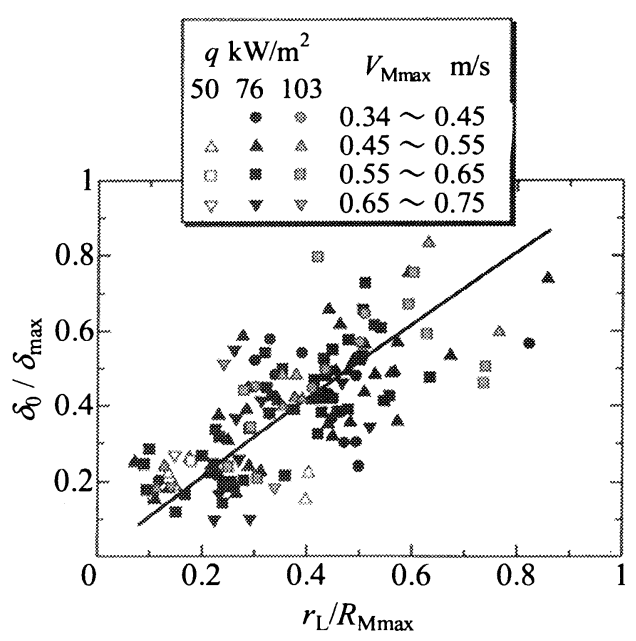

Fig.11 Relation between dimensionless micro-layer thickness and dimensionless position 
$R_{\mathrm{Mmax}}$ に達するまでのミクロ液膜半径の平均成長速度 $V_{\text {Mmax }}$ と熱流束 $q$ をパラメータとして示している. 本 測定の範囲ではそれらのパラメー夕に対する依存性は 見られず，無次元ミク口液膜厚さは式(7)のように無次 元位置に対して一通りに決まることが分かる. なお, この関係式は式(1)および（5）から導かれる関係と一 致する.

$$
\frac{\delta_{0}}{\delta_{\max }}=\frac{r_{\mathrm{L}}}{R_{\mathrm{M} \max }}
$$

\section{5. ミク口液膜蒸発に間する検时}

式(2), (5)および式(6), (7)に最大ミクロ液膜半径 $R_{\mathrm{M} \max }$ を与えることにより, $t_{\mathrm{Bd}}, \delta_{\max }$ が決まり, それ らから伝熱面上の初期ミクロ液膜厚さ $\delta_{0}$ の分布およ びミクロ液膜存在時間 $\Delta t_{\mathrm{Me}}$ が決定される.

ここでは, 以下の条件を与えることにより, ミクロ 液膜が伝熱面から沸騰気泡へ伝える熱量および生成 蒸気量を計算する.

1）初期ミクロ液膜の特性・構造は, 熱流束によらず一定 である.

2）液膜が非常に薄く, 存在時間短いことから, 烝発期 間中に液膜内の液体移動はなく, ミク口液膜は伀熱面 から沸騰気泡入熱云導のみで蒸発する.

3）ミクロ液膜のドライアウト領域で，その熱流束をゼ 口とおく.

4) 沸駦領域は核弗滕の子瓜立気泡域とし，他の気泡からの 干渉はない.

5)離跑泡形状を回転棈円体とみなし，式(3)，(4)により 蒸気泡体積を求める.

ミクロ液膜は, 過熱度 $\Delta T$ を駆動力としてミクロ液 膜を通して熱伝導により蒸発し, 初期ミク口液膜厚さ $\delta_{0}$ から時間と共にその厚さを減少させていく. それら の関倸は式(8)および(9)によって定められる.

$$
\begin{aligned}
& \delta(t)=\delta_{0}-\frac{q}{\rho_{l} L} t \\
& q=k \frac{\Delta T}{\delta(t)}
\end{aligned}
$$

なお，上記1）は図 11 の結果を表しており, また4)の 条件に関連して, Moissis-Berenson ${ }^{(3)}$ は孤立気泡域から, 気 泡干渋域と孤立気泡域が入り混じった第一遷移域への遷移 熱流束 $q_{r}$ を式(10)で与えている.

$$
q_{t r}=0.11 \rho_{v} L \cdot \theta^{0.5}\left[\frac{g \sigma}{\left(\rho_{l}-\rho_{v}\right)}\right]
$$

本研究の親水・撥水処理を施していないガラス面において は，水の一般的な接触角は $20^{\circ} \sim 40^{\circ}$ であり, 遷移熱流束の
範井は $q_{t r}=105 \sim 149 \mathrm{~kW} / \mathrm{m}^{2}$ と計算される. 本夹験の熱流 束の範冊惊熱流束側で $103 \mathrm{~kW} / \mathrm{m}^{2}$ であり, 本測定の領域 は観察結果と同様に，孤立気泡域にあることになる.

単一の気泡において, ミクロ液膜が生成されてから 最大ミク口液膜半径 $R_{\mathrm{Mmax}}$ に達し, その後減少・消滅 するまでの間, すなわち, 半径 $r$ の位置におけるミク 口液膜期間 $\Delta t_{\mathrm{Mc}}$ 内の沸騰気泡へ伝える熱量の総計 $Q_{\mathrm{ML}}$ は，式(8),(9)を用いれば式(11)のように表される.

$$
Q_{\mathrm{ML}}=\int_{0}^{R_{\text {max }}} 2 \pi r \int_{0}^{\Delta t_{\text {Met }}}\left[k \Delta T /\left(\delta_{0}-\frac{q}{\rho_{l} L} t\right)\right] d t d r
$$

図 12 は熱流束が一定条件 $q=76 \mathrm{~kW} / \mathrm{m}^{2}$ におけるミ ク口液膜厚さの時間変化を式(8)から計算した結果を 表している. $t=0$ はミクロ液膜が生成した瞬間で, 気 泡の外側へ向かうほどミクロ液膜期間は短くなる. 蒸 発によりミクロ液膜厚さは減少してゆき, 発泡点の近 傍では初期ミク口液膜厚さが小さいため, $\delta=0$ とな るドライアウトが生じる場合が現れる.

図 13 は, 孤立気泡域の熱流束範囲における, ミクロ

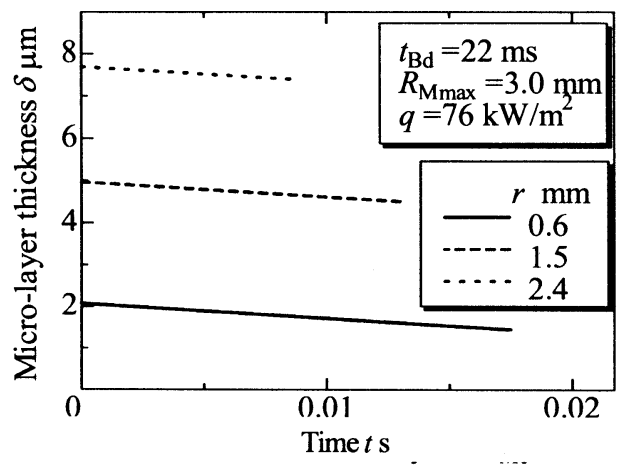

Fig.12 Variation of micro-layer thickness

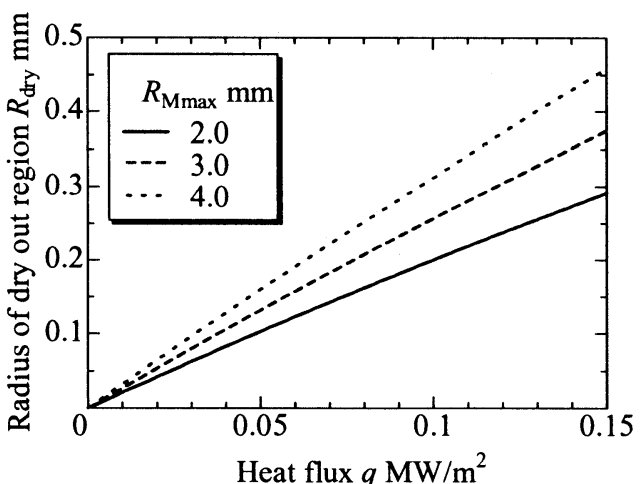

Fig.13 Variation of radius of dry out region against heat flux 


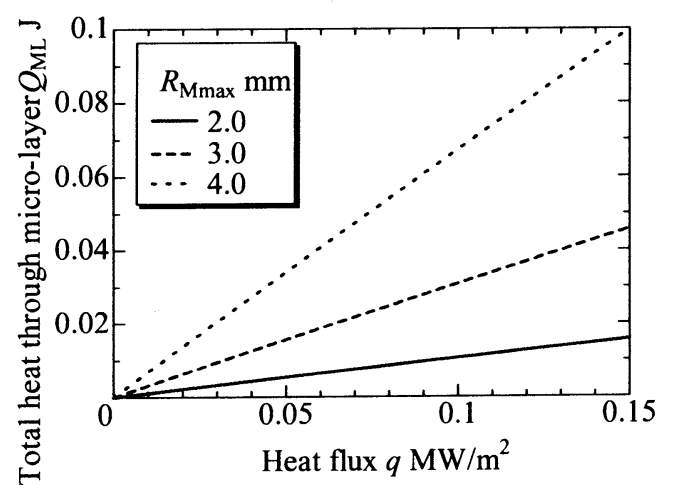

Fig.14 Variation of total heat through micro-layer in single bubble against heat flux

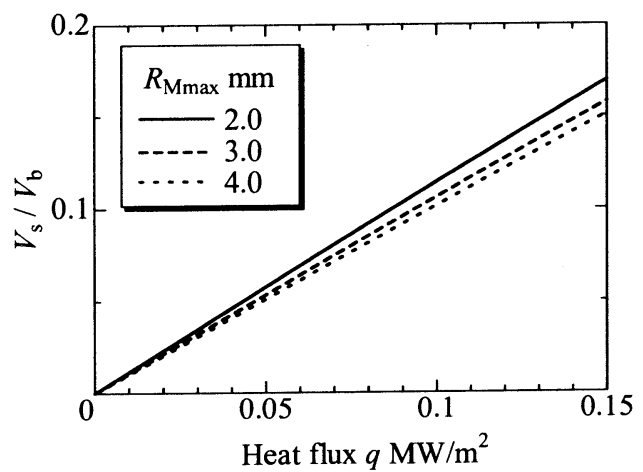

Fig.15 Contribution of evaporation from micro-layer 液膜のドライアウト部分の半径と熱流束の関係を, 最 大ミクロ液膜半径 $R_{\mathrm{Mmax}}$ をパラメータとして表してい る. 本研究で用いた熱流束の範囲においては，最大ミ クロ液膜半径 $R_{\mathrm{Mmax}}$ の中心から $4 \sim 10 \%$ 部分がドライ アウトする計算結果を得た. なお, 図 13～図 15 中の シンボルは測定における熱流束値を表している.

同様に，孤立気泡域の熱流束範井において，単一の 気泡が発生してから離脱するまでの, ミクロ液膜を通 して気泡へ伝わる熱量 $Q_{\mathrm{ML}}$ と熱流束の関係を図 14 に 示した. 熱流束の増大とともに, 熱量はミクロ液膜の 存在する部分では熱流束に比例して増加するが, ドラ イアウト部の拡大とともに有効な伝熱領域が減少する ため比例関係からずれてくる.

図 15 は, 同様に孤立気泡域の熱流束範囲において, 式(12)によるミクロ液膜からの蒸発による生成蒸気体 積 $V_{s}$ と, 式(3),(4) および式(13)より求めた沸騰気泡の 全蒸気体積 $V_{\mathrm{b}}$ の比率が熱流束に対してどのように変 化するかを, 最大ミクロ液膜半径をパラメータとして 示したものである.

$$
\begin{aligned}
& V_{s}=\frac{Q_{M L}}{\rho_{v} L} \\
& V_{b}=\frac{4}{3} \pi \times{R_{\mathrm{Bd}}}^{2} \times \frac{H_{\mathrm{Bd}}}{2}
\end{aligned}
$$

本研究で用いた熱流束の範囲では, 全蒸発量に対す るミクロ液膜からの蒸発割合は 5～11\%であった. 式(10)から計算される孤立気泡域の最大熱流束 $(q=$ $\left.149 \mathrm{~kW} / \mathrm{m}^{2}\right)$ においては, 全生成蒸気量のうちミク 口液膜蒸発の影響は $16 \%$ 程度であることがわかる. 実際の核沸騰の高熱流束領域においては，本研究 の対象とする孤立気泡域とは異なり, 気泡の合体な どの複雑な影響が加わつてくることになる. 特に、限 界熱流束のメカ二ズムと関連して様々なモデルが提案 されている。それらのうち、例えばZhao et al. ${ }^{(4)}$ はミ クロ液膜の乾燥が進むことにより限界熱流束が生じる との観点から、限界熱流束を決定しているなど、高熱 流束域でのミクロ液膜の蒸発特性の検討も重要性を持 っている。ここでは参考として，大気圧下の水のプー


$\left.q_{c}=1.11 \mathrm{MW} / \mathrm{m}^{2}\right)$ 付近まで, 本研究の孤立気泡域のミ クロ液膜厚さ構造が維持されると仮定して, ミクロ液 膜からの蒸発の影響を試算してみることにする.

図 16〜19 は,それぞれ図 12〜15における物理量を,

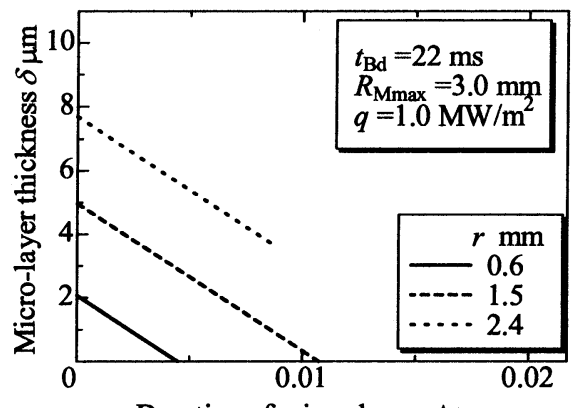

Duration of micro-layer $\Delta t_{\mathrm{Me}} \mathrm{s}$

Fig.16 Variation of micro-layer thickness

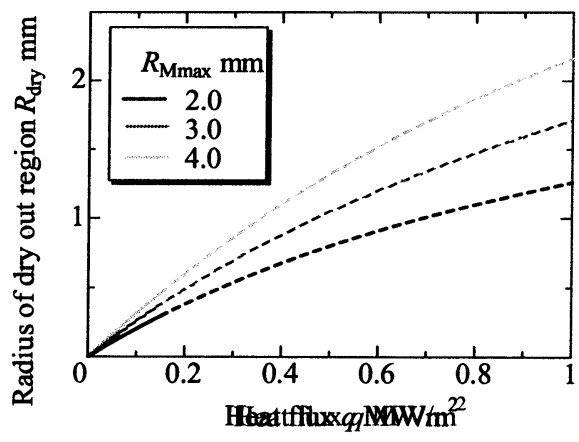

Fig. 17 Variation of radius of dry out region against heat flux 


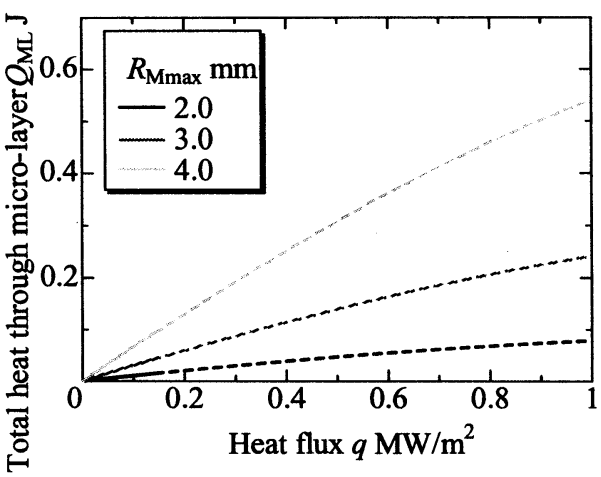

Fig.18 Variation of total heat through micro-layer in single bubble against heat flux

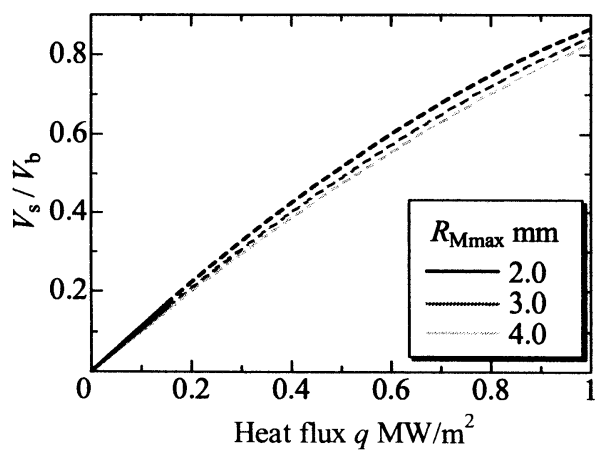

Fig.19 Contribution of evaporation from micro-layer

大気圧下の水のプール核沸騰における限界熱流束付近 まで計算したものである. 図17～19においては実線 の領域が孤立気泡域を，破線の領域が気泡干渉域を表 している. なお，本実験の範囲ではミク口液膜厚さの 熱流束への依存性はみられなかったが，ひとけた大き な熱流束付近まで本結果の適用が可能かどうか現時点 では明らかでない，しかし，発泡点密度および発泡点 からの気泡生成頻度の増加など，必ずしも熱流束の増 加がすべて気泡成長速度の増大につながるものではな く，またミク口液膜形成が流体力学的なメカ二ズムに 依存する現象であることを考えると，本実験の範囲に おける結果をより大きな熱流束範囲に拡張して検討す ることは意味を持つものと考える.

図 16 は, 最大ミク口液膜半径 $R_{\mathrm{Mmax}}$ が $3.0 \mathrm{~mm}, q=1.0$ $\mathrm{MW} / \mathrm{m}^{2}$ の条件におけるミクロ液膜厚さの時間変化を 示している. 図 8 の測定結果によれば, $r=1.5 \mathrm{~mm}$ に おけるミク口液膜期間 $\Delta t_{\mathrm{Me}}$ は8 $80 \mathrm{~ms}$ 程度の範囲に あるが，限界熱流束点付近の非常に高い熱流束におい ては $r=1.5 \mathrm{~mm}$ で $11 \mathrm{~ms}$ 程度でドライアウトが生じて
いることがわかる. したがって, 本測定の程度のミク 口液膜厚さが生じる場合には，熱流束の増大にともな って急速な乾燥が進み, ドライアウト領域が広く出現 することが推測される.

図 17 に, ミクロ液膜のドライアウト部半径と熱流束の 関係を, 最大ミクロ液膜半径 $R_{\mathrm{M} \text { max }}$ をパラメータとし て示した. 熱流束の增加にともなってドライアウト部 半径は増大するが，その増加割合はドライアウト領域 の増加により低下していく傾向を示している. 熱流束 $1.0 \mathrm{MW} / \mathrm{m}^{2}$ では中心から $54 \sim 63 \%$ 部分がドライアウト する計算結果を得た。

図 18 は熱流束に対する単一の気泡が発生してから 離脱するまでの，ミク口液膜を通して気泡へ伝わる熱 量 $Q_{\mathrm{ML}}$ の変化を示している. 図 17 のドライアウト部 半径の変化と類似して, 高熱流束においてはドライア ウトの影響が現れるため, ミクロ液膜を通して気泡へ 伝わる熱量 $Q_{\mathrm{ML}}$ は熱流束と比例関係にはならないこ とが分かる.

沸騰気泡の全蒸気量体積 $V_{\mathrm{b}}$ に占めるミクロ液膜か らの蒸発による生成蒸気体積 $V_{\mathrm{s}}$ の割合を図 19 に示し た. 全生成蒸気に対するミクロ液膜からの生成蒸気は 熱流束の増加とともに大きくなっていき, $q=1.0$ $\mathrm{MW} / \mathrm{m}^{2}$ では 80\%程度になり, 高熱流束ではミク口液 膜蒸発の影響が強くなる傾向が読及取れる． $R_{\mathrm{Mmax}}$ の 影響は小さく，ほぼ熱流束だけの関数として表される 傾向を示した.

\section{6. 結 瞽}

プール核沸騰過程において伀熱面上の沸騰気泡下部 に生成するミクロ液膜の厚さの測定から得られたミク 口液膜の厚さ構造を基に，ミク口液膜蒸発に関する伝 熱特性の検討を行い，以下の結論を得た.

（1）実験を行った熱流束範囲において，気泡成長にと もなうミク口液膜の成長速度は相似的に変化する ことから，ミク口液膜に関する主要な特性量であ るミクロ液膜厚さおよびミクロ液膜の存在時間を 最大ミク口液膜半径の関数として無次元形で表し た.

（2）ミク口液膜特性の整理結果を基に，核沸騰の孤立 気泡域におけるミク口液膜からの蒸発量を求め, その貢献度を明らかにした．すなわち，本実験の 熱流束範囲において, ミクロ液膜からの生成蒸気 量は全沸騰気泡蒸気体積に対し 5 11\% の寄与を しており，その寄与度は熱流束が大きくなるほど 増加する傾向を示した. 孤立気泡域ではミクロ液 膜からの蒸発が全蒸発量の最大 $16 \%$ 程度である 
と推測された.

本研究の一部は科学研究費補助金 (基盤研究(B) 17360096）の補助を受けて遂行された.

\section{文 献}

(1) Cooper, M.G, Lloyd, A.J.P., The microlayer in nucleate pool boiling. Int. J. Heat and Mass Transfer. Vol.12, (1969) pp.895-913.

(2) Utaka, Y., Nakamura, K., Sakurai, A., Itagaki, K. and Sonoda, A., Configuration of Micro-layer in Nucleate Boiling, Transactions of the Japan Society of Mechanical Engineers (Series B), (2008), in press.
(3) Moissis, R, and Berenson, P.J., On the Hydrodynamic Transitions in Nucleate Boiling, Journal of Heat Transfer, 85-3, (1963) pp.221-229.

(4) Zhao, Y., Masuoka, T. and Tsuruta, T., Prediction of Critical Heat Flux Based on the Microlayer Model, Transactions of the Japan Society of Mechanical Engineers (Series B), Vol.62, No.598, (1996) pp.2338-2343.

(5) Zuber, N., On stability of boiling heat transfer, Transactions of the American Society of Mechanical Engineers, 80-3, (1958) pp.711-720. 